\title{
The Encarsia noyesi species-group (Hymenoptera, Chalcidoidea, Aphelinidae) in the Neotropical region, with a key and description of the male of $E$. andrewi from Mexico
}

\author{
Svetlana Nikolaevna Myartseva', Gregory Allyn Evans², \\ Juana María Coronado-Blanco'
}

I Facultad de Ingeniería y Ciencias, Universidad Autónoma de Tamaulipas, Ciudad Victoria, 87149, Tamaulipas, México 2 USDA/APHIS/PPQ Beltsville, MD 20705, USA

Corresponding author: Juana María Coronado-Blanco (jmcoronado@uat.edu.mx)

Academic editor: S.Schmidt | Received 19 February 2014 | Accepted 21 May 2014 | Published 26 September 2014

http://zoobank.org/36095194-156C-4E48-BCA1-7E8F28052447

Citation: Myartseva SN, Evans GA, Coronado-Blanco JM (2014) The Encarsia noyesi species-group (Hymenoptera, Chalcidoidea, Aphelinidae) in the Neotropical region, with a key and description of the male of E. andrewi from Mexico. Journal of Hymenoptera Research 39: 33-46. doi: 10.3897/JHR.39.7307

\begin{abstract}
The Encarsia noyesi group species known to occur in the Neotropical region are reviewed. Taxonomic, host and distribution information for these eight species, and a key to females and males are provided. The male of E. andrewi (Myartseva and Coronado-Blanco) is described from Mexico. Aleurodicus dugesii Cockerell is reported as a new host record for $E$. andrewi.
\end{abstract}

\section{Keywords}

Aphelinidae, Encarsia, Neotropical, noyesi species-group

\section{Introduction}

The Aphelinidae is a moderately sized family of the Chalcidoidea with currently about 1350 species in 36 genera (Noyes 2013). The known fauna occurring in Mexico consists of 189 species representing 13 genera (Myartseva et al. 2012, 2013a, 2013b, Kim and Heraty 2012). Many of the species that have been used successfully in classical biological control

Copyright S.N. Myartseva et al. This is an open access article distributed under the terms of the Creative Commons Attribution License (CC BY 4.0), which permits unrestricted use, distribution, and reproduction in any medium, provided the original author and source are credited. 
projects directed against major diaspidid and aleyrodid pests around the world, have been aphelinids (Greathead 1986, Rosen and DeBach 1990, Arredondo-Bernal et al. 2008).

The genus Encarsia Förster consists of about 400 known species (Noyes 2013), and is by far the most diverse group within the subfamily Coccophaginae. Females of nearly all of the species are primary endoparasitoids of Aleyrodidae or Diaspididae. A few species have been recorded from soft scales, hormaphidine aphids, psyllids and eggs of various insect orders. Males are generally known to be hyperparasitoids. In Mexico, 99 species of Encarsia are known (Evans 2008, Myartseva et al. 2012, 2013a, 2013b).

Various authors have designated species groups for Encarsia species which share a combination of morphological characters (Viggiani and Mazzone 1979, Hayat 1989, 1998, Heraty and Polaszek 2000, Polaszek et al. 2004, Schmidt and Polaszek 2007). In the last catalog of Encarsia of the world, Heraty et al. (2007) listed 344 species of Encarsia known worldwide of which all but 80 species were placed in one of 30 species-groups. Many species clearly belong to one of these defined groups; however, the placement of some species remains tentative until more information on the world fauna and the degree of interspecific variation in some morphological structures and coloration is known. The genus Encarsia is represented in Mexico by 20 species-groups, including five species in the noyesi group (Myartseva and Evans 2008). The noyesi species-group was established by Schmidt and Polaszek (2007) for a number of species which were formerly placed in the genus Encarsiella Hayat, and appears to be monophyletic. The genus Encarsiella was erected by Hayat (1983) for one described (E. noyesi Hayat) and two undescribed species. Since then, nine new species have been described, including three species from Mexico (Myartseva and Coronado-Blanco 2002, 2004, Myartseva et al. 2013a), and four species that were transferred from other genera to Encarsiella. Polaszek and Hayat (1992) provided a key to the species of Encarsiella, and diagnoses, illustrations and other data for the species known at that time. Later the genus Encarsiella was synonymized with Encarsia on the basis of molecular and morphological characters (Schmidt and Polaszek 2007). A total of 14 species of the noyesi species-group are currently known and occur in Central, South America, Australasian and Oriental regions. Most of the species are associated with hosts of the whitefly subfamily Aleurodicinae of family Aleyrodidae, which is primarily distributed in the Neotropical region (Schmidt and Polaszek 2007).

Some species of the Encarsia noyesi species-group have been studied as natural enemies of whitefly pests and have been used successfully for biological control of whiteflies in Central America. Encarsia aleurodici (Girault) and E. noyesi (Hayat) have been used against Aleurodicus cocois (Curtis) (Cock 1985) and an undescribed Encarsia species was introduced into Nevis (Caribbean Islands) for the biological control of Aleurodicus pulvinatus (Maskell), a serious pest of coconuts and many ornamental plants, and appears to have become established (Kairo et al. 2001). Currently, Encarsia noyesi has been studied as a potential biological control agent of Aleurodicus dugesii (Cockerell) in ornamental plants in California, USA (Dreistadt et al. 2001), and also attacks Aleurodicus rugioperculatus Martin, a recently introduced invasive whitefly in Florida. The goals of this work are to review the eight species of Encarsia that belong to the Encarsia noyesi species-group in the Neotropical region, provide taxonomic, biological and distribution data and a key to the females and males of these eight species. 


\section{Abbreviations}

BMNH The Natural History Museum, Department of Entomology, London, UK. NRCBC National Reference Centre for Biological Control, Colima, Mexico.

UCRC University of California, Riverside, California, Entomological Museum, USA. USNM U.S. National Museum of Natural History, Washington D.C., USA.

\section{Results}

\section{Encarsia noyesi species-group (Aphelinidae, Coccophaginae)}

Diagnosis. Maxillary palp 2-segmented. Pronotum medially narrow and membranous. Antenna 8-segmented in both sexes, female antennal clava with sensory complex, oblique suture between fifth and sixth flagellar segments and the obliquely truncate apical segment. Mid lobe of mesoscutum with more than 30 setae. Axilla large, strongly projecting forwards and separated medially by less than the maximum length of one axilla. Fore wing hyaline or infuscate, with weakly developed stigmal vein, marginal fringe very short. Basitarsus of mid leg with a variable number of robust, spine-like setae.

Encarsia noyesi species-group is the sister group of the $E$. smithi species group, but the latter has 10 or fewer setae on mid lobe of mesoscutum, the apical segment of the antenna is not obliquely truncate, and the first segment of funicle is quadrate to slightly longer than wide, about 0.5 times as long as second segment.

\section{Key to females and males of Neotropical species of Encarsia noyesi group}

Female

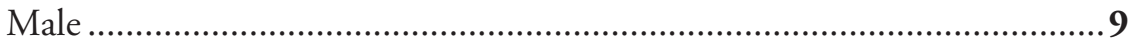

2 Fore wing infuscate below marginal vein....................................... andrewi

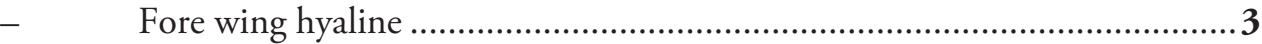

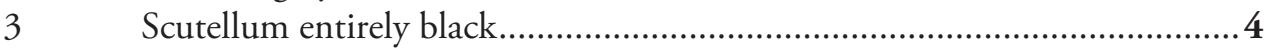

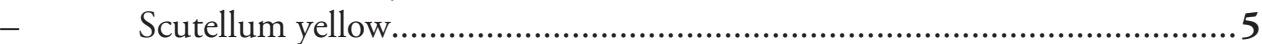

$4 \quad$ Ovipositor as long as mid tibia.......................................................eleurodici

- $\quad$ Ovipositor 1.3 times as long as mid tibia ....................................tamaulipeca

$5 \quad$ Gaster orange yellow at base and with yellow tip. Legs white. Fore wing with two large setae and 2-4 small setae on submarginal vein............. magniclava

- $\quad$ Gaster brownish black. Legs partly brownish. Fore wing with two long setae on submarginal vein.................................................................................6

6 Base of fore wing with an infuscate area basally. Pedicel entirely pale... pithecura

- $\quad$ Base of fore wing hyaline. Pedicel infuscate partly or entirely dark...............7

7 Second segment of funicle white, with black apical 1/3-1/2. First segment of funicle slightly shorter than pedicel and without sensilla. Ovipositor longer than mid tibia. Third valvula 0.7 times as long as second valvifer.... nayarita 
- $\quad$ Second segment of funicle completely yellow. First segment of funicle about as long as pedicel and with sensilla. Ovipositor shorter than mid tibia

8 Fore wing with a long band bare of setae along anterior margin and without asetose area below stigmal vein. Second segment of funicle somewhat longer than first and third segments. Mid tibial spur 0.9 times as long as basitarsus

noyesi

- $\quad$ Fore wing without a long band bare of setae along anterior margin and with asetose area below stigmal vein. Second and third segments of funicle subequal in length and shorter than first segment. Mid tibial spur 0.7 times as long as basitarsus narroi

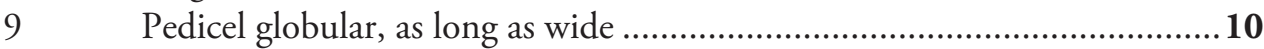

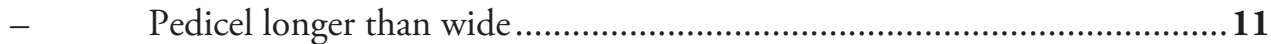

10 Flagellum unicolored, yellow. Scutellum yellowish medially ............ andrewi Flagellum bicolored, with some dark segments. Scutellum completely dark brown noyesi

11 Club longer than two preceding funicular segments combined. Mid lobe of mesoscutum with strong imbricate/reticulate sculpture aleurodici - $\quad$ Club as long as two preceding funicular segments combined. Mid lobe of mesoscutum with elongate/reticulate sculpture. tamaulipeca

\section{Review of Neotropical species of the Encarsia noyesi group}

\section{Encarsia aleurodici (Girault, 1916)}

Coccophagus aleurodici Girault, 1916: 401. Syntype females and male. Trinidad: British West Indies, xii.1914, F. W. Urich, ex. Aleurodicus on Theobroma bicolor, in USNM. Prospaltella aleurodici (Girault); Compere 1931: 11.

Dirphys aleurodici (Girault); Hayat 1989: 59.

Encarsiella aleurodici (Girault); Viggiani 1986: 59.

Encarsia aleurodici (Girault); Schmidt and Polaszek 2007: 81.

Diagnosis. This species was redescribed by Viggiani (1986) and Polaszek and Hayat (1992). Female: body entirely dark brown. Fore wing hyaline. Legs dark brown except as follow: distal half of femur and tibia of fore leg, distal half of tibia of mid leg pale, hind tibia brown-yellow, all tarsi pale. Antennal (Fig. 1) radicle, pedicel, first segment of funicle and club dark brown, scape light yellow with brown dorsal margin of distal half, second segment pale brown, third segment yellow. Third valvula pale yellow. Mouth fossa narrower than width of frontovertex at front ocellus. Mid lobe of mesoscutum, scutellum and axillae with strong imbricate/reticulate sculpture. Ovipositor about as long as mid tibia. Male with pedicel of antenna (Fig. 2) longer than wide and slightly shorter than first funicle segment. 

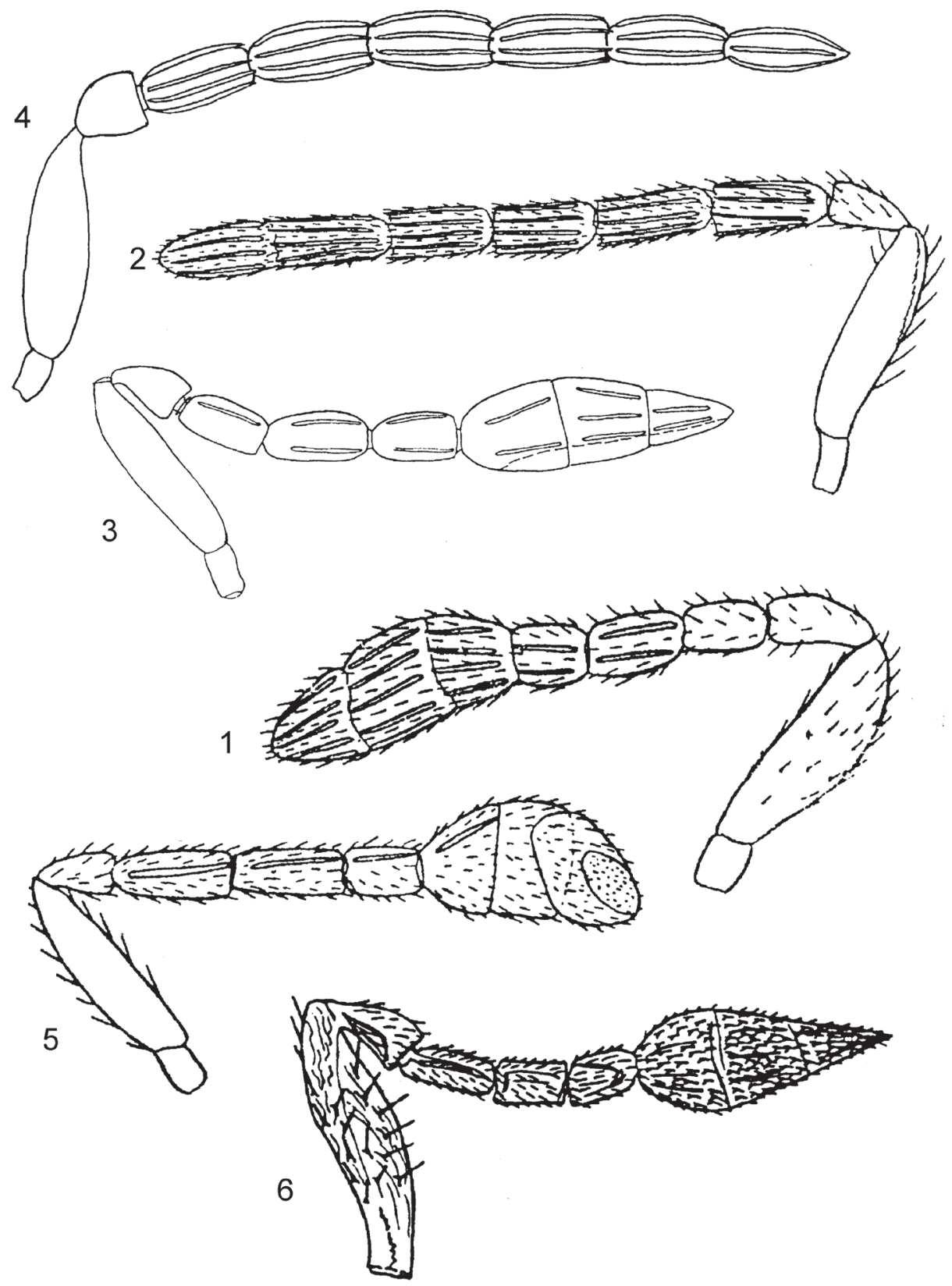

Figures I-6. Antennae of Encarsia spp.: I aleurodici, female $\mathbf{2}$ male $\mathbf{3}$ andrewi, female $\mathbf{4}$ male $\mathbf{5}$ magniclava, female $\mathbf{6}$ narroi, female.

Distribution. Bahamas, Barbados, Bermuda, Brazil, Costa Rica, Ecuador, Trinidad and Tobago (Noyes 2013).

Hosts. Aleurodicus sp., A. capiangae Bondar, A. cocois (Curtis), A. dispersus Russell. 
Comments. Notes on the biology of $A$. capiangae (host selection, oviposition) were published by Mound (1961). In 1966, this parasitoid was introduced into Brazil from Trinidad against Aleurodicus cocois (Carvalho et al. 1971).

\section{Encarsia andrewi Myartseva \& Coronado-Blanco, 2008}

Encarsiella polaszeki Myartseva \& Coronado-Blanco, 2004: 229. Holotype female. Mexico: Tamaulipas, Jaumave, 30.IV.2000, S. Myartseva, ex. Aleurodicinae, in UCRC.

Encarsia polaszeki (Myartseva \& Coronado-Blanco, 2004); Schmidt and Polaszek 2007: 81.

Encarsia andrewi Myartseva \& Coronado-Blanco, 2008: 67, previous name preoccupied by Encarsia polaszeki Evans, 1997.

Diagnosis. Female: head yellow, frontovertex orange. Antenna (Fig. 3) yellow, first and second segments of club brown, pedicel and first segment of funicle infuscate. Mesosoma yellow, pronotum, mid lobe of mesoscutum and axillae dark orange or fuscous. Legs light yellow. Fore wings infuscate below marginal vein. Gaster dark brown, third valvula light yellow. Eye more than 1.5 times as long as cheek. Antennal scape 4.0-4.2 times as long as wide, pedicel 1.7 times as long as wide, segments of funicle about twice as long as wide each, club slightly shorter than funicle. All flagellar segments with longitudinal sensilla. Fore wing twice as long as wide. Mid tibial spur 0.8 times as long as basitarsus. Ovipositor exserted, 1.2 times as long as mid tibia, third valvula 0.7 times as long as second valvifer.

Male (first description). Length of body: $0.7 \mathrm{~mm}$. Head coloration as in female, antenna uniformly dark yellow with sensilla brown. Mesosoma dark brown, side lobes yellow with dark spot apically, scutellum light brown laterally and yellow medially. Fore wing hyaline. Legs yellow; hind coxa, femur and base of tibia infuscate. Gaster brownish black. Eye 1.6 times as long as cheek. Antennal scape 4.0 times as long as wide, pedicel very slightly longer than wide (15:13). First segment of funicle slightly shorter than second segment (6:7) and about 3 times as long as wide; second to sixth segments about 4 times as long as wide each. Club not expressed (Fig. 4). All flagellar segments with 4 linear sensilla each. Fore wing 2.4-2.7 times as long as wide, base with 4 setae, marginal vein with $8-9$ setae along anterior margin. Hind wing 8.0 times as long as maximum width of wing, its marginal fringe 0.8 times as long as wing width. Genitalia 0.8 times as long as mid tibia.

Material. Mexico: Tamaulipas, Altamira, ex Aleurodicus dugesii Cockerell on epiphyte plant Struthanthus sp. (Loranthaceae) on unknown tree, 4 males, 23.V.2013 (coll. E. Ruíz-Cancino).

Distribution. Mexico (Querétaro, Tamaulipas).

Hosts. Aleurodicinae unspecified sp. (possibly Aleurodicus sp.), Aleurodicus dugesii Cockerell. First record of epiphyte plant Struthanthus sp. as host for A. dugesii. 
Comments. A new name Encarsia andrewi nom. nov. was proposed by Myartseva et al. (2008) for E. polaszeki (Myartseva and Coronado-Blanco 2004), which was preoccupied by E. polaszeki Evans, 1997, a species described from Brazil.

\section{Encarsia magniclava (Girault, 1915)}

Coccophagus magniclavus Girault, 1915: 33. Syntype females. British Guiana (=Guyana):

Berbice, Demarara, iii.1993, G. E. Bodkin, ex. Aleurochiton sp., in USNM.

Prospaltella magniclava (Girault); Compere 1931: 31.

Encarsiella magniclava (Girault); Viggiani 1986: 66.

Dirphys magniclavus (Girault); Hayat 1989: 288.

Encarsia magniclava (Girault); Schmidt and Polaszek 2007: 81.

Diagnosis. This species was briefly redescribed by Viggiani (1986); Polaszek and Hayat (1992) provided a more complete redescription of the species. Female: body deep orange yellow, the following parts black: head around occiput, pronotum, antennal club, apex of axillae, suture along apical margin of scutellum. Gaster orange yellow at base and black dorsally. Legs white. Fore wing hyaline. Third valvula yellow. Antennal (Fig. 5) pedicel very slightly longer than wide; first and second segments of funicle subequal in length, each 2.4 times as long as wide and 1.5 times as long as pedicel; third segment as long as pedicel. Segments of club wider than long. Fore wing with two large setae and 2-4 smaller setae on submarginal vein, marginal vein with 14-16 setae along anterior margin. Ovipositor about as long as mid tibia. Male: unknown.

Distribution. Guyana, Panama (Noyes 2013).

Hosts. Aleurochiton sp., Eudialeurodicus bodkini Quaintance \& Baker (Noyes 2013).

\section{Encarsia narroi Gómez \& García, 2000}

Encarsia narroi Gómez \& García, 2000: 49. Holotype female. Mexico: Parras, Coahuila, 1500 masl, 11.ii.1995, Gómez and García, ex. Aleurodicus sp., on Baubinia variegata, in NRCBC; Schmidt and Polaszek 2007: 81.

Encarsiella narroi (Gómez \& García); Myartseva and Coronado-Blanco 2004: 624.

Diagnosis. Female: body brown, scutellum pale yellow, antennal funicle and legs pale yellow, hind femora infuscate. Pedicel subequal in length to first segment of funicle (Fig. 6). Fore wing hyaline, with small asetose area below stigmal vein, about 2.3 times as long as wide, with 10 basal group setae. Mid tibial spur 0.7 times as long as basitarsus. Male: unknown.

Distribution. Mexico (Coahuila).

Hosts. Aleurodicus sp. 


\section{Encarsia nayarita Myartseva, 2013}

Encarsia nayarita Myartseva, 2013b: 646-649. Holotype female. Mexico: Nayarit, Jalisco, Universidad Autonoma de Nayarit, 18.IX.2012, S. Myartseva, ex. Aleurodicus coccolobae on Myrtus communis, in UCRC.

Diagnosis. Female: head yellow, face and orbits of eyes white, in living female pearlish-bluish-white, occiput black. Antenna white, scape and pedicel dorsally black, first segment of funicle completely, third to half of second segment black, upper part of third segment slightly infuscate. Club, excluding whitish base and third segment, black. Mesosoma black, scutellum light yellow, in living female pearlishbluish-white, side lobes light yellow, with dark spot on apical part. Fore wing hyaline. Legs white, basal part of mid coxae, hind coxae and half basal part of femora dorsally black. Gaster black, third valvula white. Eye slightly longer than cheek. Mandible 3-dentate. Antennal scape (Fig. 7) 4.6 times as long as wide, pedicel 1.8 times as long as wide. First segment of funicle 0.6 times as long as second segment and 1.7 times as long as wide; second segment 2.5 times as long as wide; third segment twice as long as wide. First segment of funicle without sensilla. Sculpture of mesoscutum longitudinally reticulate. Fore wing twice as long as wide, its base with 10-14 short setae. Mid tibial spur slightly longer than basitarsus. Ovipositor exserted, 1.1 times as long as mid tibia, third valvula 0.7 times as long as second valvifer. Male: unknown.

Distribution. Mexico (Nayarit).

Hosts. Aleurodicus coccolobae Quaintance \& Baker.

\section{Encarsia noyesi (Hayat, 1983)}

Encarsiella noyesi Hayat, 1983: 85. Holotype female. Trinidad: St. George, St. Augustine, xi.1976, F. D. Bennett, in BMNH; Polaszek and Hayat 1992: 195; Myartseva and Coronado 2002: 623.

Dirphys noyesi (Hayat); Hayat 1989: 7.

Encarsia noyesi (Hayat); Schmidt and Polaszek 2007: 81.

Diagnosis. Female: head with frontovertex orange, face pale, occiput brownish. Antenna (Fig. 8) with second and third segments of funicle yellow, club dark brown. Body brownish-black, scutellum pale yellow, in living female pearlish-bluish-white. Legs pale yellow, mid and hind coxae and hind femora infuscate. Third valvula pale, with black apices. Fore wing hyaline, with a long bare band along wing margin, 8-10 basal group setae, 9 setae on marginal vein. Mid tibial spur 0.9 times as long as basitarsus. Ovipositor as long as mid tibia, third valvula 0.6 times as long as second valvifer. Male similar to female, except for darker coloration and structure of antenna (Fig. 9) and genitalia. 

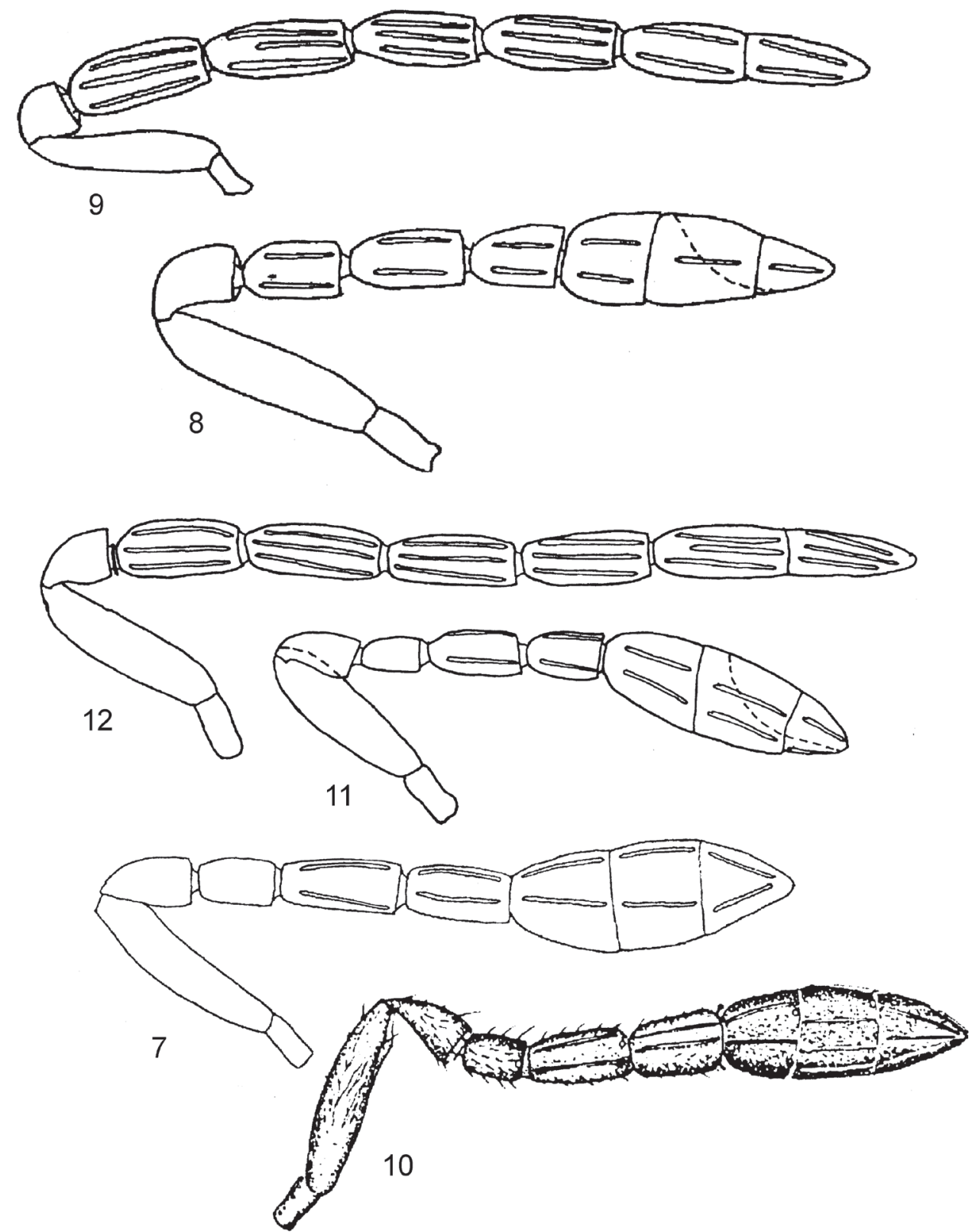

Figures 7-12. Antennae of Encarsia spp.: $\mathbf{7}$ nayarita, female $\mathbf{8}$ noyesi, female $\mathbf{9}$ male $\mathbf{1} \mathbf{0}$ pithecura, female I I tamaulipeca, female $\mathbf{2}$ male.

Distribution. Anguilla, Antigua, Barbados, Bermuda, Costa Rica, Grenada, Mexico, Peru, St. Vincent and Grenadines, Trinidad and Tobago, USA (California, Florida) (Noyes 2013). In Mexico, this species has been found in Jalisco, San Luis Potosí, Tamaulipas, Yucatán (Myartseva and Evans 2008). 
Hosts. Aleurodicus chirripoensis Martin, A. cocois, A. dispersus, A. dugesii Cockerell, A. maritimus Hempel, A. rugioperculatus Martin, and Aleurothrixus floccosus (Maskell). It has been reported from Nipaecoccus aurilanatus (Maskell), Puto barberi (Cockerell) (Pseudococcidae), probably as a hyperparasitoid (Noyes 2013).

Comments. Encarsia noyesi has been used to control Aleurodicus dugesii in Florida (Nguyen and Hamon 2002) and also attacks Aleurodicus rugioperculatus, a newly introduced, invasive whitefly in Florida (Taravati et al. 2013), and A. chirripoensis, new pest of banana in Costa Rica (Sánchez and Laprade 2013).

\section{Encarsia pithecura (Polaszek, 1999)}

Encarsiella pithecura Polaszek, in Martin and Polaszek 1999: 1557-1558. Holotype female. Belize: Cayo District, Chiquibul Forest Reserve, Las Cuevas-Monkey Tail trail, 5.iii.1996, J.H. Martin, ex. Azuraleurodicus pentarthus, in BMNH; Myartseva and Coronado-Blanco 2002: 624.

Encarsia pithecura (Polaszek, 1999); Schmidt and Polaszek 2007: 81.

Diagnosis. Female: head and body largely brownish-black. Antennal scape, pedicel and third segment of funicle pale, first, fourth to sixth segments brown, second segment pale brown; face, scrobes and clypeus pale. Mesosoma and gaster brownish black, scutellum, tip of seventh tergite and third valvula entirely pale. Legs pale yellow/brown except all coxae and hind femora brown. Fore wing hyaline, except for a small circular patch basally, faintly infuscate. Antennal scape (Fig. 10) very slightly expanded, about 2.5 times as long as pedicel. First segment of funicle shorter than pedicel and without sensilla; fifth and sixth segments partly fused, claval sensorial complex developed, the oblique suture dividing these segments absent on part of the ventral surface. Fore wing with 6-8 setae in basal cell. Ovipositor slightly shorter than mid tibia, second valvifer 2.5 times as long as third valvula. Male: unknown.

Distribution. Belize.

Hosts. Azuraleurodicus pentarthus Martin (Martin and Polaszek 1999).

\section{Encarsia tamaulipeca (Myartseva \& Coronado-Blanco, 2002)}

Encarsiella tamaulipeca Myartseva \& Coronado-Blanco, 2002: 621. Holotype female. Mexico: Tamaulipas, Ciudad Victoria, 7-8.xii.1995, S. Myartseva, ex. Aleyrodidae on Psidium guajava, in USNM.

Encarsia tamaulipeca (Myartseva \& Coronado-Blanco, 2002); Schmidt and Polaszek 2007: 81.

Diagnosis. Female: head black, face ferrugineous from anterior ocellus to interantennal prominence and whitish below (except upper margin of mouth, hind part of cheeks and 
antennal scrobes). Pedicel and club brown, scape (except distal half dorsally) and third funicular segment whitish, first and second segments pale brown. Mesosoma and gaster black. Fore wings hyaline. Legs yellowish-white, mid and hind coxae, hind femora black, mid femora and hind tibiae infuscate. Third valvula whitish. Eye 2 times as long as cheek. Antennal scape (Fig. 11) 4 times as long as wide; pedicel 1.7 times as long as wide and slightly longer than first segment of funicle; first to third segments of funicle 1.5, 1.8 and 1.3 times as long as wide, respectively. Club slightly longer than funicle. First segment of funicle without sensilla. Fore wing more than twice as long as wide, its base with 7-10 setae, marginal fringe very short. Hind wing more than 4.5 times as long as wide. Mid tibial spur slightly shorter than basitarsus. Ovipositor exserted, longer than mid tibia (14:11), third valvula 0.5 times as long as second valvifer. Male differs by head and body more dark coloration, and structure of antenna (Fig. 12) and genitalia.

Distribution. Mexico (Tamaulipas).

Hosts. Aleurodicinae unspecified sp. (possibly Aleurodicus sp.).

\section{Acknowledgements}

Many thanks to E. Ruíz-Cancino (Universidad Autónoma de Tamaulipas, Cd. Victoria, Tamaulipas, México) for his help in the collecting of specimens of Aphelinidae, to V. E. Carapia Ruíz (Universidad Autónoma del Estado de Morelos) for identification of whiteflies and to Jacinto Treviño Carreón and Arturo Mora Olivo (Universidad Autónoma de Tamaulipas) for identification of epiphyte plant. Thanks to University of Tamaulipas for financial support of this study.

\section{References}

Arredondo Bernal HC, Mellén Rosas MA, Jiménez Jiménez E (2008) Mosca prieta de los cítricos, Aleurocanthus woglumi (Hemiptera: Aleyrodidae). In: Arredondo Bernal HC, Rodríguez del Bosque LA (Eds) Casos de Control Biológico en México. Mundi Prensa México, SA de CV, 333-346.

Carvalho MB de, Freitas A de O, Arruda GP de (1971) Some observations on Aleurodicus cocois (Curtis, 1846) (Homoptera, Aleyrodidae), the cashew 'white fly' in the State of Pernambuco. Boletim Tecnico do Instituto de Pesquisas Agronomicas 18: 1-20.

Chou KC, Chou LY (1994) A new species of Encarsiella (Hymenoptera: Aphelinidae) from Taiwan. Journal of Agricultural Research (China) 43(4): 469-472.

Cock MJW (Ed.) (1985) A review of biological control of pests in the Commonwealth Caribbean and Bermuda up to 1982. Technical Communication, Commonwealth Institute of Biological Control 9: 1-218.

Compere H (1931) A revision of the species of Coccophagus a genus of hymenopterous coccidinhabiting parasites. Proceedings of the United States National Museum 78: 1-132. doi: $10.5479 /$ si.00963801.78-2850.1 
Dreistadt SH, Clark JK, Flint ML (2001) Integrated Pest Management for Floriculture and Nurseries.

Oakland. Univ. of California, Agriculture and Natural Resources, Publication 3402.

Evans GA (1997) A new Encarsia (Hymenoptera: Aphelinidae) species reared from the Bemisia tabaci complex (Homoptera: Aleyrodidae). Florida Entomologist 80(1): 24-27. doi: $10.2307 / 3495972$

Evans GA (2008) The whiteflies (Hemiptera: Aleyrodidae) of the world and their host plants and natural enemies, 703 pp. [Computer version 2008-09-23]

Girault AA (1915) Australian Hymenoptera Chalcidoidea - VII. Memoirs of the Queensland Museum 4: 1-184.

Girault AA (1916) Three new species of Coccophagus, family Encyrtidae (Hym.). Entomological News 27: 33-34.

Gómez J, García O (2000) A new species of Encarsia (Hymenoptera: Aphelinidae), a parasitoid of whitefly Aleurodicus sp. (Homoptera: Aleyrodidae) in Mexico. Pan-Pacific Entomologist 76(1): 49-51.

Greathead D (1986) Parasitoids in classical biological control. In: Waage J, Greathead D (Eds) Insect parasitoids. Academic Press, London, 289-318.

Hayat M (1983) The genera of Aphelinidae (Hymenoptera) of the world. Systematic Entomology 8: 63-102. doi: 10.1111/j.1365-3113.1983.tb00467.x

Hayat M (1989) A revision of the species of Encarsia Forster (Hymenoptera: Aphelinidae) from India and the adjacent countries. Oriental Insects 23: 1-131.

Hayat M (1998) Aphelinidae of India (Hymenoptera: Chalcidoidea): a taxonomic revision. Memoirs on Entomology 13: 1-416.

Heraty JM, Polaszek A (2000) Morphometric analysis and descriptions of selected species in the Encarsia strenua group (Hymenoptera: Aphelinidae). Journal of Hymenoptera Research 9(1): 142-169. http://www.biodiversitylibrary.org/page/2858443\#page/148/mode/1 up

Heraty J, Woolley J, Polaszek A (2007) Catalog of the Encarsia of the World, 87 pp. http:// www.faculty.ucr.edu/ - heraty/Encarsia.cat.pdf

Huang J, Polaszek A (1996) The species of Encarsiella Hayat (Hymenoptera: Aphelinidae) from China. Journal of Natural History 30: 1649-1659. doi: 10.1080/00222939600770971

Kairo MTK, López VF, Pollard GV, Hector R (2001) Biological control of the coconut whitefly, Aleurodicus pulvinatus, in Nevis. Biocontrol News and Information 22(2): 45N-50N.

Kim JW, Heraty J (2012) A phylogenetic analysis of the genera of Aphelininae (Hymenoptera: Aphelinidae), with a generic key and descriptions of new taxa. Systematic Entomology 37: 497-549. doi: 10.1111/j.1365-3113.2012.00625.x

Martin J, Polaszek A (1999) A new genus of Neotropical whitefly, secreting blue-iridescent wax (Sternorrhyncha, Aleyrodidae, Aleurodicinae), and its parasitoids (Hymenoptera, Aphelinidae). Journal of Natural History 33: 1545-1559. doi: 10.1080/002229399299888

Mound LA (1961) A new genus and four new species of whitefly from ferns (Homoptera, Aleyrodidae). Revue de Zoologie et de Botanique Africaines 64: 127-132.

Myartseva SN, Evans GA (2008) Genus Encarsia Förster of Mexico (Hymenoptera: Chalcidoidea: Aphelinidae). A revision, key and description of new species. Serie Avispas Parasíticas de Plagas y Otros Insectos, 3. Universidad Autónoma de Tamaulipas, Ciudad Victoria, 320 pp. 
Myartseva SN, Coronado-Blanco JM (2002) A new parasitoid of whiteflies from Mexico, with a key to New World species of the genus Encarsiella (Hymenoptera: Aphelinidae). Florida Entomologist 85(4): 620-624. doi: 10.1653/0015-4040(2002)085[0620:ANPOWF]2.0. CO;2, http://journals.fcla.edu/flaent/article/view/75150/72808

Myartseva SN, Coronado-Blanco JM (2004) A new species of Encarsiella Hayat (Hymenoptera: Aphelinidae) with a key to Mexican species. Folia Entomológica Mexicana 43(2): 227-232. Myartseva SN, Ruíz-Cancino E, Coronado-Blanco JM (2008) Encarsia aurantii speciesgroup (Hymenoptera: Aphelinidae), parasitoids of armored scales (Hemiptera: Diaspididae) in Mexico, with key and description of a new species. Zoosystematica Rossica 7(1): 67-71.

Myartseva SN, Ruíz-Cancino E, Coronado-Blanco JM (2012) Aphelinidae (Hymenoptera: Chalcidoidea) de importancia agrícola en México. Revisión y claves. Serie Avispas Parasíticas de Plagas y otros Insectos No. 8. Universidad Autónoma de Tamaulipas, México, 413 pp. [Publication on CD]

Myartseva SN, Ruíz-Cancino E, Coronado-Blanco JM (2013a) Four new species of Aphelinidae (Hymenoptera: Chalcidoidea) from Mexico. Zootaxa 3641(3): 223-232. doi: 10.11646/ zootaxa.3641.3.2

Myartseva SN, Ruíz-Cancino E, Coronado-Blanco JM, Cambero-Campos J (2013b) Parasitoides de Aleurodicus spp. (Hemiptera: Aleyrodidae) en México, con la descripción de una nueva especie de Encarsia (Hymenoptera: Aphelinidae). Acta Zoológica Mexicana (n.s.) 29(3): 641-653. http://www1.inecol.edu.mx/azm/AZM29(3)-2013/AZM-29-3-mMyartseva.pdf

Nguyen R, Hamon AB (2002) Biological control of giant whitefly, Aleurodicus dugesii Cockerell, in Florida. http://www.freshfromflorida.com/pi/methods/giant-whitefly-bc.html [accessed July 2012]

Noyes JS (2013) Universal Chalcidoidea Database [online]. Worldwide Web electronic publication. http://www.nhm.ac.uk/entomology/chalcidoids/index.html [last updated: October 2013]

Polaszek A, Hayat M (1992) A revision of the genera Dirphys Howard and Encarsiella Hayat (Hymenoptera: Aphelinidae). Systematic Entomology 17: 181-197. doi: 10.1111/j.13653113.1992.tb00329.x

Polaszek A, Manzari S, Quicke DL (2004) Morphological and molecular taxonomic analysis of the Encarsia meritoria species-complex (Hymenoptera, Aphelinidae), parasitoids of whiteflies (Hemiptera, Aleyrodidae) of economic importance. Zoologica Scripta 33(5): 403-421. doi: 10.1111/j.0300-3256.2004.00161.x

Rosen D, DeBach P (1990) Ectoparasites. In: Rosen D (Ed.) Armored scale insects. Vol. 4B. Elsevier, Amsterdam, 99-120.

Sánchez CG, Laprade SC (2013) Aleurodicus chirripoensis Martin, 2008 (Sternorrhyncha: Aleyrodidae): una nueva plaga de mosca blanca que afecta al banano en Costa Rica. Dugesiana 20(2): 89-91.

Schmidt S, Polaszek A (2007) Encarsia or Encarsiella? - redefining generic limits based on morphological and molecular evidence (Hymenoptera, Aphelinidae). Systematic Entomology 32: 81-94. doi: 10.1111/j.1365-3113.2006.00364.x 
Taravati S, Mannion C, Glenn H, Osborne L (2013) Natural enemies of Rugose Spiraling Whitefly, Aleurodicus rugioperculatus Martin (Insecta: Hemiptera: Aleyrodidae) in the south Florida landscape. University of Florida, Entomology and Nematology Department, UF/IFAS extension ENY-870: 1-6. http://edis.ifas.ufl.edu/pdffiles/IN/IN100400. pdf [accessed January 8, $2014 \mathrm{att}$ ]

Viggiani G (1986) Notes on some species of Coccophagus Westwood, Coccophagoides Girault, Encarsia Foerster and Encarsiella Hayat (Hymenoptera: Aphelinidae), mainly from the Nearctic and Neotropical regions. Bollettino del Laboratario di Entomologia Agraria 'Filippo Silvestri' di Portici 43: 59-78.

Viggiani G, Mazzone P (1979) Contributi alla conoscenza morfo-biologica delle specie del complexo Encarsia Foerster - Prospaltella Ashmead (Hymenoptera, Aphelinidae). 1. Un commento sull'attuate stato, con proposte sinonimiche e descrizione di Encarsia silvestrii n. sp. parásita di Bemisia citricola Gom. Men. (Homoptera, Aleyrodidae). Bollettino del Laboratorio di Entomologia Agraria "Filippo Silvestri” di Portici 36: 42-50. 